\title{
DETERMINAN PRAKTIK PERSONAL HYGIENE MAHASISWA UNIVERSITAS DIPONEGORO SEBAGAI BENTUK PENCEGAHAN DALAM SITUASI PANDEMI COVID-19
}

\author{
Nadira Esthevyani ${ }^{a^{*}}$; Yusniar Hanani Darundiati ${ }^{b}$; Nur Endah Wahyuningsih ${ }^{c}$ \\ a, b,c Fakultas Kesehatan Masyarakat: Bagian Kesehatan Lingkungan, Universitas Diponegoro ; \\ Semarang 50275; Indonesia
}

\begin{abstract}
Abstrak
COVID-19 telah ditetapkan sebagai pandemi pada skala global. Kurangnya menjaga kualitas personal hygiene dapat menjadi penyebab rentannya penularan COVID-19, hal ini menjadi perhatian terutama bagi mahasiswa perantauan yang harus melakukan karantina baik di indekos, asrama, atau rumah kontrakan. Penelitian ini bertujuan untuk mengetahui determinan praktik personal hygiene mahasiswa Universitas Diponegoro sebagai bentuk pencegahan dalam situasi pandemi COVID-19. Penelitian ini berjenis kuantitatif dengan observasional analitik menggunakan pendekatan cross-sectional. Penentuan sampel menggunakan proportional random sampling pada 442 responden dengan pengambilan data penelitian didapat melalui kuesioner online dan dianalisa secara univariat dan bivariat. Responden paling banyak berjenis kelamin perempuan $(71,7 \%)$, memiliki pengetahuan tentang praktik personal hygiene yang kurang baik $(27,4 \%)$, memiliki sikap tentang praktik personal hygiene yang kurang baik $(45,2 \%)$, memiliki lingkungan sosial yang tidak mendukung $(55,2 \%)$, tidak dapat menjangkau akses informasi $(46,2 \%)$, dan memiliki praktik personal hygiene yang kurang baik $(40,7 \%)$. Ada hubungan antara jenis kelamin $(\mathrm{p}=0,001)$, sikap tentang praktik personal hygiene $(\mathrm{p}=0,001)$, dukungan sosial $(\mathrm{p}=0,001)$, dan akses informasi $(\mathrm{p}=0,001)$ dengan praktik personal hygiene responden. Praktik personal hygiene kurang baik pada mahasiswa Universitas Diponegoro lebih banyak ditemukan pada mahasiswa berjenis kelamin laki-laki dan sikap tentang praktik personal hygiene yang kurang baik.
\end{abstract}

Kata kunci: praktik personal hygiene; pencegahan COVID-19; mahasiswa

\begin{abstract}
[DETERMINANTS OF PERSONAL HYGIENE BEHAVIOUR OF DIPONEGORO UNIVERSITY STUDENTS AS A FORM OF PREVENTION IN THE COVID-19 PANDEMIC SITUATION] COVID-19 has been declared a pandemic on a global scale. Lack of maintaining the quality of personal hygiene can make the transmission of COVID-19 vulnerable, especially for college students who have to do quarantine either in boarding houses, dormitories, or rented houses. This study aims to see the determinants of the personal hygiene practices of Diponegoro University students as a form of prevention in the COVID-19 pandemic situation. This research used quantitative study with observational analytic and cross-sectional approach. The samples are determined using proportional random sampling on 442 respondents and collected the data through online questionnaires and analyzed using univariate and bivariate tests. Most of the respondents were female $(71.7 \%)$, had poor knowledge of personal hygiene practices $(27.4 \%)$, had poor attitudes on personal hygiene practices $(45.2 \%)$, had a poor social support $(55.2 \%)$, inaccessible information $(46.2 \%)$, and had poor personal hygiene practices $(40.7 \%)$. There's a relation between gender $(p=0.001)$, attitudes on personal hygiene practices $(p=0.001)$, social support $(p=0.001)$, and access to information $(p=0.001)$ with the respondent's personal hygiene practices. Poor personal hygiene practices among Diponegoro University students were more often found in male students and poor attitudes on personal hygiene practices.
\end{abstract}

Keywords: personal hygiene practice; COVID-19 prevention; college students

\section{Pendahuluan}

Pada awal tahun 2020, terjadi peningkatan kasus penyakit menular yang disebabkan oleh

\footnotetext{
*) Corresponding Author (Nadira Esthevyani)

E-mail: nadiraesthevyani@gmail.com
}

virus dan telah menyebar ke beberapa negara lainnya, yaitu coronavirus (Yuliana, 2020). Hingga saat ini, dapat dipastikan sebanyak 215 negara telah terjangkit coronavirus, penyebab dari COVID-19 per tanggal 7 Desember 2020 
dengan jumlah penderita secara global sebanyak 66.243.918 jiwa dengan jumlah kematian sebanyak 1.528.984 jiwa Case Fatality Rate (CFR) akibat COVID-19 sebesar 2,3\% (World Health Organization, 2020)

Indonesia dilaporkan mendapati kasus pertama terinfeksi coronavirus sebanyak 2 orang pada tanggal 2 Maret 2020. Kedua pasien tersebut menunjukkan hasil positif terinfeksi coronavirus yang memiliki riwayat kontak langsung dengan Warga Negara Asing (WNA) dari Jepang setelah menghadiri suatu acara di Jakarta. Kedua pasien mengeluhkan gejala-gejala seperti batuk, sesak napas, dan demam (World Health Organization, 2020; Yuliana, 2020)

Total jumlah kasus COVID-19 di Indonesia setiap harinya semakin meningkat sejak dilaporkannya kasus pertama. Tercatat per tanggal 7 Desember 2020 sebanyak 581.550 kasus positif dengan jumlah kematian sebanyak 17.867 jiwa. Kasus positif terbanyak berada di Provinsi DKI Jakarta sebanyak 143.961 kasus, Jawa Timur sebanyak 65.012 kasus, Jawa Tengah sebanyak 60.514 kasus, Jawa Barat sebanyak 59.273 kasus, dan Sulawesi Selatan sebanyak 21.569 kasus. Kasus COVID-19 ditemukan pada kelompok usia yaitu 31-45 tahun (30,4\%), 19-30 tahun (24,6\%), 46-59 tahun $(23,1 \%), \geq 60$ tahun $(10,4 \%), 6-18$ tahun $(8,8 \%)$, dan 0-5 tahun (2,7\%). Selain itu, jumlah CFR secara nasional sebesar 3,1\%. CFR COVID-19 di Indonesia ini sama dengan CFR secara global (Komite Penanganan COVID-19 dan Pemulihan Ekonomi Nasional, 2020).

Provinsi Jawa Tengah merupakan salah satu wilayah di Indonesia dengan jumlah CFR COVID-19 melebihi CFR secara nasional yaitu sebesar 6,4\% dengan jumlah kasus positif sebanyak 60.514 kasus dan jumlah kematian sebanyak 3.929 jiwa per tanggal 26 November 2020. Penderita paling banyak ditemukan pada usia produktif yang terbagi ke dalam 3 kelompok usia yaitu 31-45 tahun (26,8\%), 46-59 tahun $(25,8 \%)$, dan 19-30 tahun (20,8\%). Mengingat jumlah penderita COVID-19 di Provinsi Jawa Tengah paling banyak ditemukan pada kelompok usia produktif, maka perlu dilakukan penanggulan, penanganan, dan pencegahan yang baik (Komite Penanganan COVID-19 dan Pemulihan Ekonomi Nasional, 2020).

Anjuran untuk mengurangi penularan COVID-19 ialah tidak melakukan kontak langsung dengan penderita COVID-19. Apabila kontak langsung tidak dapat dihindarkan, maka pencegahan yang dapat dilakukan ialah menjaga kualitas personal hygiene dengan baik. Personal hygiene yang baik dapat melindungi tubuh terserang berbagai penyakit, baik menular maupun tidak menular (Manyullei, Utama, \& Birawida, 2012). Personal hygiene merupakan langkah utama yang sangat efektif untuk mencegah penularan COVID-19 karena COVID-19 ditularkan melalui cipratan droplets yang sangat mudah masuk ke dalam tubuh seseorang melalui sistem pernapasan atau dari kontak langsung dengan penderita COVID-19 (World Health Organization, 2020). Pencegahan COVID-19 melalui personal hygiene dapat dilakukan dengan cara menjaga kebersihan tangan secara teratur dengan cara mencuci tangan menggunakan sabun dan air mengalir, menjaga jarak aman dengan orang lain, melakukan etika batuk atau bersin dan menggunakan masker, serta tidak menyentuh permukaan wajah (UNICEF, 2020).

Mahasiswa perantauan yang tinggal di tempat kost, asrama, atau rumah kontrakan rentan terserang penyakit, baik penyakit tidak menular maupun menular. Penyebab utama dari permasalahan tersebut karena kurangnya perhatian untuk menjaga personal hygiene masing-masing mahasiswa. Hal tersebut juga didukung oleh adanya situasi pandemi COVID-19 karena ada yang tidak dapat kembali ke kampung halaman sehingga harus menetap di tempat kost, asrama, atau rumah kontrakan untuk membatasi dan mengurangi paparan coronavirus. Hal ini dilakukan karena adanya kemungkinan tempat asalnya juga merupakan wilayah zona hitam COVID-19. Meskipun demikian, sebagian mahasiswa perantauan yang dapat kembali ke kampung halaman atau mahasiswa bukan perantauan yang berada di rumah masing-masing juga terdapat kemungkinan tidak dapat menjaga kualitas kebersihan pribadinya.

Mahasiswa tergolong sebagai salah satu kelompok usia yang paling tinggi persentase penderitanya $(24,7 \%)$. Mahasiswa dari Universitas Diponegoro terpilih menjadi subjek penelitian ini karena Universitas Diponegoro dikenal sebagai universitas terbesar di Kota Semarang, Provinsi Jawa Tengah dan diharapkan dapat merepresentasikan praktik personal hygiene di kalangan mahasiswa dalam hal pencegahan COVID-19.

Tujuan penelitian ini ingin mengetahui determinan praktik personal hygiene mahasiswa Universitas Diponegoro sebagai bentuk pencegahan dalam situasi pandemi COVID-19 
meliputi karakteristik mahasiswa (jenis kelamin), pengetahuan tentang praktik personal hygiene, sikap tentang praktik personal hygiene, dukungan sosial, dan akses informasi.

\section{Metode Penelitian}

Penelitian ini berjenis kuantitatif dengan desain studi observasional analitik menggunakan pendekatan cross-sectional yang dilakukan pada bulan Agustus 2020. Populasi penelitian ini ialah mahasiswa Universitas Diponegoro yang terdaftar aktif pada Biro Administrasi Akademik Universitas Diponegoro di tahun akademik 2019/2020 sebanyak 48.808 mahasiswa.

Sampel ditentukan secara proportional random sampling yaitu menentukan secara acak pada masing-masing jumlah sub populasi fakultas yang terdaftar pada Biro Administrasi Akademik Universitas Diponegoro dengan total sampel yang digunakan sebanyak 442 sampel. Jika jumlah total minimal sampel telah tercapai, maka peneliti akan melakukan pengecekan sampel di tiap masing-masing sub populasi. Apabila total jumlah minimal sampel yang didapat di tiap masing-masing sub populasi telah melebihi minimal jumlah sampel per sub populasi yang telah ditentukan, maka sampel akan dipilih secara acak dengan menggunakan nomor undian. Nomor undian akan disesuaikan jumlahnya dengan banyaknya jumlah sampel tiap sub populasi. Setiap nomor yang terpilih akan peneliti kembalikan sehingga setiap sampel memiliki kesempatan yang sama untuk terpilih. Apabila total jumlah sampel yang didapat di tiap masing-masing sub populasi kurang dari minimal jumlah sampel per sub populasi yang telah ditentukan, maka peneliti akan melakukan penyebaran kuesioner penelitian kembali hingga jumlah sampel sesuai dengan jumlah sampel yang telah ditentukan per sub populasi atau lebih dari itu.

Instrumen penelitian berupa kuesioner daring yang disebar melalui media sosial berupa LINE, instagram, dan twitter untuk melakukan pengambilan data, baik disebar melalui group chat atau beranda media sosial menggunakan platform google form. Kuesioner penelitian yang akan digunakan sebelumnya diuji kevalidan dan reliabiltasnya melalui 30 responden diluar dari subjek penelitian Hasil uji validitas dan reliabilitas yang didapatkan dari penelitian ini ialah valid dan reliabel, sehingga dapat dikatakan kuesioner pada penelitian ini layak untuk dijadikan sebagai alat ukur penelitian atau intrumen penelitian.

Analisis dilakukan secara univariat untuk mendistribusikan frekuensi dan analisis bivariat menggunakan uji Chi square untuk menganalisa hubungan antara variabel jenis kelamin, pengetahuan tentang praktik personal hygiene, sikap tentang praktik personal hygiene, dukungan sosial, dan akses informasi dengan praktik personal hygiene responden. Kategori variabel dibagi menjadi dua yang mengacu pada median dari hasil skor total jawaban responden karena data pada penelitian ini berdistribusi tidak normal. Kategori variabel jenis kelamin dibagi menjadi laki-laki dan perempuan, variabel pengetahuan dan sikap tentang praktik personal hygiene menjadi buruk dan baik, variabel dukungan sosial menjadi tidak mendukung dan mendukung, dan variabel akses informasi menjadi tidak dapat dijangkau dan dapat dijangkau. Penelitian ini telah lolos uji etik oleh Komisi Etik Penelitian Kesehatan Fakultas Kesehatan Masyarakat Universitas Diponegoro dengan nomor 176/EA/KEPK-FKM/2020.

\section{Hasil dan Pembahasan}

Hasil uji univariat menunjukan dari 442 responden, responden paling banyak berjenis kelamin perempuan $(71,7 \%)$. Selain itu, responden memiliki pengetahuan tentang praktik personal hygiene yang kurang baik $(27,4 \%)$, memiliki sikap tentang praktik personal hygiene yang kurang baik $(45,2 \%)$, memiliki lingkungan sosial yang tidak mendukung $(55,2 \%)$, tidak dapat menjangkau akses informasi $(46,2 \%)$, dan memiliki praktik personal hygiene yang kurang baik (40,7\%) (Tabel 2$)$. 
Tabel 1. Hasil Jawaban yang Menarik dari Mahasiswa Universitas Diponegoro yang Buruk yang Berada di Kota Semarang maupun Luar Kota Semarang selama Situasi Pandemi COVID-19 pada Bulan Agustus 2020

\begin{tabular}{lcc}
\hline \multicolumn{1}{c}{ Variabel } & $\begin{array}{c}\text { Frekuensi } \\
\text { (n) }\end{array}$ & $\begin{array}{c}\text { Persentase } \\
\text { (\%) }\end{array}$ \\
\hline $\begin{array}{l}\text { Pengetahuan terkait Praktik Personal Hygiene } \\
\text { 1. Responden memahami dengan baik dan benar bahwa personal } \\
\text { hygiene adalah salah satu indikator pencegahan penularan } \\
\text { COVID-19 }\end{array}$ & 437 & 89,9 \\
$\begin{array}{l}\text { Sikap terkait Praktik Personal Hygiene } \\
\text { 2. Responden setuju bahwa tidak perlu menghindari keramaian } \\
\text { asalkan sudah mengenakan masker }\end{array}$ & 238 \\
$\begin{array}{l}\text { Dukungan Sosial } \\
\text { 3. Masih sedikit orang tua dan atau saudara yang mengingatkan } \\
\text { untuk menjaga jarak setidaknya 1 meter dengan orang lain }\end{array}$ & 175 \\
$\begin{array}{l}\text { 4. Responden jarang diingatkan oleh teman untuk menjaga jarak } \\
\text { setidaknya 1 meter dengan orang lain }\end{array}$ & 174 \\
$\begin{array}{l}\text { Praktik Personal Hygiene } \\
\text { 5. Responden lebih banyak yang masih mengabaikan jaga jarak } \\
\text { aman dengan orang lain saat berada di keramaian }\end{array}$ & 236 \\
$\begin{array}{l}\text { 6. Responden selalu menutup mulut atau hidung ketika batuk atau } \\
\text { bersin menggunakan telapak tangan }\end{array}$ & 133 \\
\hline
\end{tabular}

Terdapat hubungan signifikan antara jenis kelamin dengan praktik personal hygiene responden. Perbedaan jenis kelamin menjadi penyebab perbedaan dalam mengambil tindakan pencegahan COVID-19. Hal ini sesuai dengan teori Lawrance Green yang menyatakan bahwa terdapat tiga faktor yang berpengaruh terhadap perilaku kesehatan yaitu faktor predisposisi (predisposing), pemudah (enabling), dan penguat (reinforcing). Karakteristik responden berdasarkan jenis kelamin termasuk sebagai faktor predisposisi. Jenis kelamin merupakan faktor predisposisi atau faktor pemungkin terciptanya sebuah perilaku karena menjadi sebuah pemicu latar belakang alasan atau motivasi yang kuat dalam melakukan perilaku kesehatan (Green \& Kreuter, 1991; Porter, 2015). Berdasarkan stimulus atau pemicu yang didapat,

Tabel 2. Hasil Uji Univariat pada Mahasiswa Universitas Diponegoro yang Berada di Kota Semarang maupun Luar Kota Semarang selama Situasi Pandemi COVID-19 pada Bulan Agustus 2020

\begin{tabular}{|c|c|c|}
\hline Variabel & $\begin{array}{c}\text { Frekuensi } \\
\text { (n) }\end{array}$ & $\begin{array}{c}\text { Persentase } \\
(\%)\end{array}$ \\
\hline \multicolumn{3}{|l|}{ Jenis kelamin } \\
\hline Laki-laki & 125 & 28,3 \\
\hline Perempuan & 317 & 71,7 \\
\hline \multicolumn{3}{|c|}{ Pengetahuan praktik personal hygiene } \\
\hline Kurang baik & 121 & 27,4 \\
\hline Baik & 321 & 72,6 \\
\hline \multicolumn{3}{|c|}{ Sikap tentang praktik personal hygiene } \\
\hline Kurang baik & 200 & 45,2 \\
\hline Baik & 242 & 54,8 \\
\hline \multicolumn{3}{|l|}{ Dukungan sosial } \\
\hline Tidak mendukung & 244 & 55,2 \\
\hline Mendukung & 198 & 44,8 \\
\hline \multicolumn{3}{|l|}{ Akses informasi } \\
\hline Tidak dapat dijangkau & 204 & 46,2 \\
\hline Dapat dijangkau & 238 & 53,8 \\
\hline \multicolumn{3}{|l|}{ Praktik personal hygiene } \\
\hline Kurang baik & 180 & 40,7 \\
\hline Baik & 262 & 59,3 \\
\hline
\end{tabular}


Tabel 3. Hasil Uji Bivariat Praktik Personal Hygiene Mahasiswa Universitas Diponegoro yang Berada di Kota Semarang maupun Luar Kota Semarang selama Situasi Pandemi COVID-19 pada Bulan Agustus 2020

\begin{tabular}{|c|c|c|c|c|c|c|c|c|}
\hline \multirow{3}{*}{ Variabel } & \multicolumn{4}{|c|}{ Praktik Personal Hygiene } & \multicolumn{2}{|c|}{ Total } & \multirow{3}{*}{ p value } & \multirow{3}{*}{$95 \% \mathrm{CI}$} \\
\hline & \multicolumn{2}{|c|}{ Kurang Baik } & \multicolumn{2}{|c|}{ Baik } & \multirow{2}{*}{$\mathrm{n}$} & \multirow{2}{*}{$\%$} & & \\
\hline & $\mathrm{n}$ & $\%$ & $\mathrm{n}$ & $\%$ & & & & \\
\hline \multicolumn{9}{|l|}{ Jenis kelamin } \\
\hline Laki-laki & 79 & 63,2 & 46 & 36,8 & 125 & 100 & \multirow{2}{*}{$0,001^{*}$} & 3,673 \\
\hline Perempuan & 101 & 31,9 & 216 & 68,1 & 317 & 100 & & $(2,381-5,666)$ \\
\hline \multicolumn{9}{|c|}{ Pengetahuan tentang praktik personal hygiene } \\
\hline Kurang baik & 48 & 39,7 & 73 & 60,3 & 121 & 100 & \multirow{2}{*}{0,782} & 0,941 \\
\hline Baik & 132 & 41,1 & 189 & 58,9 & 321 & 100 & & $(0,614-1,443)$ \\
\hline \multicolumn{9}{|c|}{ Sikap tentang praktik personal hygiene } \\
\hline Kurang baik & 111 & 55,5 & 89 & 44,5 & 200 & 100 & \multirow{2}{*}{$0,001^{*}$} & 3,127 \\
\hline Baik & 69 & 28,5 & 173 & 71,5 & 242 & 100 & & $(2,108-4,639)$ \\
\hline \multicolumn{9}{|l|}{ Dukungan sosial } \\
\hline Tidak mendukung & 125 & 51,2 & 119 & 48,8 & 244 & 100 & \multirow{2}{*}{$0,001^{*}$} & 2,731 \\
\hline Mendukung & 55 & 27,8 & 143 & 72,2 & 198 & 100 & & $(1,831-4,073)$ \\
\hline \multicolumn{9}{|l|}{ Akses informasi } \\
\hline Tidak dapat dijangkau & 107 & 52,5 & 97 & 47,5 & 204 & 100 & \multirow{2}{*}{$0,001^{*}$} & 2,493 \\
\hline Dapat dijangkau & 73 & 30,7 & 165 & 69,3 & 238 & 100 & & $(1,690-3,679)$ \\
\hline
\end{tabular}

*signifikan pada $\mathrm{p}<0,05$

Tabel 4. Hasil Uji Bivariat Pengetahuan tentang Praktik Personal Hygiene Mahasiswa Universitas Diponegoro yang Berada di Kota Semarang maupun Luar Kota Semarang selama Situasi Pandemi COVID-19 pada Bulan Agustus 2020

\begin{tabular}{|c|c|c|c|c|c|c|c|c|}
\hline \multirow{3}{*}{ Variabel } & \multicolumn{4}{|c|}{$\begin{array}{l}\text { Pengetahuan tentang Praktik } \\
\text { Personal Hygiene }\end{array}$} & \multicolumn{2}{|c|}{ Total } & \multirow{3}{*}{$p$ value } & \multirow{3}{*}{$95 \% \mathrm{CI}$} \\
\hline & \multicolumn{2}{|c|}{ Kurang Baik } & \multicolumn{2}{|c|}{ Baik } & \multirow{2}{*}{$\mathrm{n}$} & \multirow{2}{*}{$\%$} & & \\
\hline & $\mathrm{n}$ & $\%$ & $\mathrm{n}$ & $\%$ & & & & \\
\hline \multicolumn{9}{|l|}{ Jenis kelamin } \\
\hline Laki-laki & 47 & 37,6 & 78 & 62,4 & 125 & 100 & \multirow{2}{*}{$0,002^{*}$} & 1,979 \\
\hline Perempuan & 74 & 23,3 & 243 & 76,7 & 317 & 100 & & $(1,267-3,090)$ \\
\hline \multicolumn{9}{|c|}{ Sikap tentang praktik personal hygiene } \\
\hline Kurang baik & 68 & 34,0 & 132 & 41,1 & 200 & 100 & \multirow{2}{*}{$0,005^{*}$} & 1,837 \\
\hline Baik & 53 & 21,9 & 189 & 78,1 & 242 & 100 & & $(1,204-2,803)$ \\
\hline
\end{tabular}

*signifikan pada $\mathrm{p}<0,05$

Perilaku dapat dibedakan berdasarkan dua jenis yaitu perilaku tertutup (convert behaviour) dan perilaku terbuka (overt behaviour), dalam hal ini perilaku terbuka merupakan hal yang diteliti pada penelitian ini. Perilaku terbuka merupakan respon seseorang yang dapat dilihat melalui tindakan atau praktik yang dilakukannya (Notoatmodjo, 2012).

Praktik personal hygiene yang kurang baik lebih banyak ditemukan pada responden laki-laki $(63,2 \%)$ daripada responden perempuan $(31,9 \%)$ dengan hasil bahwa responden laki-laki berisiko 3,673 kali lebih besar memiliki praktik personal hygiene yang kurang baik daripada responden perempuan. Hal ini dapat terjadi karena secara umum laki-laki kurang tertarik terhadap norma sosial yang ada daripada perempuan, salah satunya norma sosial yang berorientasi pada kesehatan. Selain itu, kebutuhan untuk merawat dan menjaga kebersihan pribadi laki-laki tidak sebanyak yang dibutuhkan pada perempuan sehingga laki-laki kurang begitu memperhatikan kebersihan dirinya daripada perempuan.

Studi yang dilakukan pada 7 Universitas di Ghana menunjukkan bahwa sudah menjadi pengetahuan umum bahwa perempuan lebih sadar akan kebersihan daripada laki-laki (Odonkor, Kitcher, Okyere, \& Mahami, 2019). Walaupun sebagai seorang mahasiswa baik perempuan maupun laki-laki yang memiliki tingkat pendidikan yang lebih tinggi dan pola pikir yang lebih komprehensif, ada kemungkinan perbedaan dalam mengambil tindakan 
pencegahan COVID-19. Hal tersebut dikuatkan dengan penemuan peneliti bahwa ada hubungan antara jenis kelamin dengan pengetahuan tentang praktik personal hygiene responden pada penelitian ini $(\mathrm{p}=0,002)$.

Penelitian ini memiliki kesamaan dengan penelitian yang dilakukan pada mahasiswa di Universitas di Pakistan bahwa ada hubungan antara jenis kelamin dengan praktik kebersihan diri sebegai upaya pencegahan COVID-19. Selain itu, diketahui bahwa perempuan lebih baik dalam melakukan praktik kebersihan diri sebagai upaya pencegahan COVID-19 dibandingkan laki-laki $(\mathrm{p}=0,012)$ (Salman et al., 2020). Hal ini menguatkan bukti bahwa perempuan lebih mudah menerima norma sosial yang ada khususnya untuk kesehatannya dan lebih memperhatikan kebersihannya dibandingkan laki-laki.

Pemberian edukasi mengenai menjaga kualitas personal hygiene di perguruan tinggi, khususnya Universitas Diponegoro sangat penting untuk dilakukan dengan tujuan agar dapat menurunkan tingkat penularan penyakit COVID-19 yang saat ini menjadi masalah utama kesehatan. Mahasiswa dapat menjadi agen perubah dengan cara membentuk suatu komunitas promotor kesehatan yang dapat dipimpin oleh mahasiswa ilmu kesehatan dengan tujuan memberikan informasi dan edukasi terkait pentingnya menjaga kualitas personal hygiene dalam situasi pandemi COVID-19 saat ini. Kalangan mahasiswi dapat menjadi penggerak utama dalam melakukan pendekatan dengan mahasiswi dan mahasiswa lainnya untuk mengajak berpartisipasi dan ikut serta dalam membentuk komunitas promotor kesehatan ini. Anggota dari komunitas ini tidak hanya di fakultas kesehatan namun dapat menjangkau fakultas non kesehatan sehingga seluruh mahasiswa Universitas Diponegoro menjadi lebih sadar dan peka terkait pentingnya menjaga kualitas personal hygiene dalam situasi pandemi COVID-19 saat ini.

Hasil uji bivariat menunjukkan tidak ada hubungan signifikan antara pengetahuan tentang praktik personal hygiene dengan praktik personal hygiene responden. Hal ini dapat terjadi karena aspek penting untuk penerimaan dan terbentuknya tindakan pada seseorang adalah pengetahuan yang bersifat jangka panjang. Sebaliknya, apabila hal tersebut tidak didasari oleh pengetahuan yang bersifat jangka panjang, maka tindakan atau praktik yang dilakukan tidak akan berlangsung lama dan belum tentu terlaksana. Hal ini meningkatkan kemungkinan terjadinya perilaku abai atau ketidaksiplinan mahasiswa dalam mengimplementasikan praktik personal hygiene yang baik.

Perilaku abai atau ketidakdisiplinan ini dapat terlihat dari praktik personal hygiene mahasiswa yang kurang baik lebih sedikit ditemukan pada responden dengan tingkat pengetahuan tentang praktik personal hygiene yang kurang baik $(39,7 \%)$ daripada dengan tingkat pengetahuan tentang praktik personal hygiene yang baik (41,1\%). Mahasiswa sebenarnya sudah memahami dengan baik bahwa praktik kebersihan pribadi sebagai salah satu bentuk pencegahan COVID-19 (89,9\%). Namun, berbeda dengan implementasi praktik personal hygiene yang dilakukan. Responden lebih banyak yang masih mengabaikan jaga jarak aman dengan orang lain saat berada di keramaian $(53,4 \%)$ dan selalu menutup mulut atau hidung ketika batuk atau bersin menggunakan telapak tangan (30,1\%) seharusnya dilakukan menggunakan siku atau lengan.

Seseorang yang sudah paham dan sadar (aware) terhadap suatu hal belum tentu akan melakukan tindakan dengan benar. Hal ini perlu diberikannya stimulasi dan melalui beberapa tahap agar dapat benar-benar menerima dan memahami informasi apa yang ia dapatkan sebelum pada akhirnya seseorang tersebut dapat mengadopsi dan mengimplementasikan suatu hal, dalam hal ini ialah praktik kesehatan yang tepat (Risnawaty, 2017).

Hasil penelitian ini berbeda dengan penelitian yang dilakukan pada mahasiswi di Universitas Bisha, Saudi Arabia bahwa ada hubungan antara pengetahuan dengan praktik sebagai bentuk pencegahan dari infeksi droplet selama wabah virus corona pada mahasiswi di Universitas Bisha, Saudi Arabia $(p=0,001)$ (White, Omer, \& Mohamma, 2020). Dalam penelitian tersebut, responden yang dituju hanya pada mahasiswi di Universitas Bisha dan dijelaskan bahwa pengetahuan terkait praktik pencegahan infeksi droplet selama wabah virus corona telah dikatakan baik. Sebelumnya pada penelitian ini telah dijelaskan pula bahwa perempuan lebih mudah menerima norma sosial yang ada khususnya untuk kesehatannya dan lebih memperhatikan kebersihannya dibandingkan laki-laki. Implementasi praktik pencegahan infeksi droplet selama wabah virus corona pada mahasiswi Bisha selain didasari oleh faktor jenis kelamin juga didasari oleh baiknya penerimaan dan pemahaman mahasiswi untuk meningkatkan derajat kesehatannya. 
Hasil uji bivariat menunjukkan ada hubungan yang signifikan antara sikap tentang praktik personal hygiene dengan praktik personal hygiene responden. Hal ini dapat terjadi karena cara pandang dan penilaian mahasiswa terhadap pemasalahan COVID-19, terutama dalam mencegah COVID-19, dapat mempengaruhi implementasi praktik kebersihan pribadi yang dilakukan.

Hal ini sesuai dengan teori Lawrance Green yang menyatakan bahwa sikap seseorang menjadi faktor predisposisi terciptanya sebuah perilaku kesehatan. Sikap berbentuk opini atau pendapat dalam menilai suatu objek masalah. Penilaian timbul karena stimulus, terutama dalam hal ini masalah praktik personal hygiene sebagai bentuk pencegahan COVID-19. Stimulus ini dapat berupa bagaimana seseorang memahami cara transmisi COVID-19, manifestasi klinis yang dapat muncul jika tertular, hingga bentuk pencegahannya. Stimulus ini akan berpengaruh terhadap kualitas penilaian seseorang dan menjadi alasan seseorang dalam mengambil keputusan terciptanya implementasi praktik personal hygiene yang benar atau salah. Hal tersebut dikuatkan penemuan peneliti bahwa ada hubungan antara sikap tentang praktik personal hygiene dengan pengetahuan tentang praktik personal hygiene responden pada penelitian ini $(p=0,005)$. Stimulus ini dapat berasal dari pengelaman, pengetahuan atau wawasan, emosi, maupun pengaruh eksternal lainnya seperti media massa (Green \& Kreuter, 1991; Porter, 2015).

Praktik personal hygiene yang kurang baik lebih banyak ditemukan pada responden yang memiliki sikap tentang praktik personal hygiene yang kurang baik $(55,5 \%)$ daripada responden yang memiliki sikap tentang praktik personal hygiene yang baik $(28,5 \%)$ dengan hasil bahwa responden dengan sikap tentang praktik personal hygiene yang kurang baik berisiko 3,127 kali lebih besar memiliki praktik personal hygiene yang kurang baik daripada responden yang memiliki sikap tentang praktik personal hygiene yang baik. Terlihat dari hasil jawaban responden bahwa mahasiswa setuju bahwa tidak perlu menghindari keramaian asalkan sudah mengenakan masker (53,8\%) sehingga juga menyebabkan mahasiswa lebih banyak yang masih mengabaikan jaga jarak aman dengan orang lain saat berada di keramaian $(53,4 \%)$. Hal ini menguatkan bukti bahwa semakin kurang baik sikap mahasiswa dalam menanggapi pentingnya menjaga kualitas personal hygiene dalam mencegah penularan COVID-19, maka semakin kurang baik pula implementasi pencegahan yang dilakukan, begitu pun sebaliknya. Penelitian ini juga didukung dengan penelitian yang dilakukan pada mahasiswa sarjana di China bahwa adanya hubungan antara sikap dengan praktik terkait COVID-19 pada mahasiswa sarjana di China (signifikan pada $\mathrm{p}<0$,05) (Peng, Pei, Zheng, Wang, \& Zhang, 2020).

Kampanye edukatif di kalangan mahasiswa dapat dilakukan agar mahasiswa dapat terlatih dan terbiasa dalam menyikapi dengan baik dan terbiasa dalam menyikapi dengan baik dan benar tentang pandemi COVID-19 khususnya pada praktik personal hygiene. Hal ini juga dibutuhkan peran dari pihak Universitas Diponegoro agar memberikan dukungan kepada mahasiswa dalam menyelenggarakan kampanye edukatif ini, baik dalam ikut serta menjadi pembicara maupun dalam ikut mempromosikan kampanye ini.

Terdapat hubungan yang signifikan antara dukungan sosial dengan praktik personal hygiene responden. Hal ini dapat terjadi karena lingkungan sosial seseorang baik dari orang tua maupun teman, sangat mempengaruhi dorongan seseorang untuk melakukan suatu tindakan. Kurangnya dukungan dari lingkungan sosial mahasiswa dalam menjaga kualitas kebersihan pribadi untuk mencegah COVID-19 dapat menyebabkan kurangnya kesadaran dalam menjaga kesehatan dan kebersihan tubuh sehingga lebih rentan untuk tertular penyakit ini.

Dukungan sosial yang memadai telah dilaporkan memiliki efek positif penentuan terjadinya praktik kesehatan. Mahasiswa dengan lingkungan sosial dengan pemahaman yang baik terkait permasalahan kesehatan yang saat ini menjadi permasalahan penting, yaitu COVID-19 serta dikelilingi oleh lingkungan sosial yang sadar akan gaya hidup sehat cenderung berpikir bahwa mereka sebenarnya rentan terhadap penyakit tersebut dan akan lebih tergerak untuk melakukan hal-hal pencegahan agar dirinya tetap sehat. Namun, jika mahasiswa tidak mendapatkan lingkungan yang mendukung, hal ini tentu akan berpengaruh terhadap implementasi dan kualitas dari personal hygiene tiap individu.

Hal ini sesuai dengan teori Lawrance Green yang menyatakan bahwa dukungan sosial merupakan faktor yang dapat memperkuat atau mendukung perilaku kesehatan tersebut dapat terjadi agar perilaku tersebut dapat berkelanjutan. Dukungan sosial berperan untuk meningkatkan dorongan seseorang dalam melakukan perilaku kesehatan yang lebih baik lagi (Green \& Kreuter, 
1991; Porter, 2015).

Dukungan sosial memainkan peran kunci dalam kesejahteraan dan menjadi salah satu kunci utama sebagai pendukung dalam mengurangi penyebaran COVID-19 (Saltzman, Hansel, \& Bordnick, 2020). Selama masa krisis seperti saat ini, dukungan sosial terkait pencegahan COVID-19 dengan menjaga kualitas praktik personal hygiene sangat ditekankan terutama bagi kalangan mahasiswa yang saat ini harus melakukan karantina baik di rumah bersama keluarga atau saudara maupun karantina mandiri di tempat kost, asrama, atau kontrakan masing-masing karena tidak ada pengawasan atau perhatian langsung dari orang terdekatnya dalam menjaga kualitas praktik personal hygiene guna mencegah penyebaran virus.

Praktik personal hygiene yang kurang baik lebih banyak ditemukan pada responden dengan lingkungan sosial yang tidak mendukung $(51,2 \%)$ daripada responden dengan lingkungan sosial yang mendukung $(27,8 \%)$ dengan hasil bahwa responden yang memiliki lingkungan sosial tidak mendukung berisiko 2,731 kali lebih besar memiliki praktik personal hygiene yang kurang baik daripada responden yang memiliki lingkungan sosial yang mendukung. Terlihat dari hasil jawaban responden bahwa masih sedikit orang tua dan atau saudara yang mengingatkan untuk menjaga jarak setidaknya 1 meter dengan orang lain $(39,6 \%)$ dapat menyebabkan mahasiswa lebih banyak yang masih mengabaikan jaga jarak aman dengan orang lain saat berada di keramaian $(53,4 \%)$. Terlihat bahwa semakin tidak mendukungnya lingkungan sosial seseorang selama situasi pandemi COVID-19 saat ini, maka semakin tidak maksimal implementasi pencegahan yang dilakukan, begitu pun sebaliknya. Hal tersebut didukung oleh penelitian yang dilakukan pada masyarakat Filipina di Luzon, Filipina bahwa adanya hubungan antara norma subjektif dengan perilaku pencegahan nyata COVID-19 $(\mathrm{p}=0,001)$ (Prasetyo, Castillo, Salonga, Sia, \& Seneta, 2020).

Orang tua dari mahasiswa dapat menginisiasi untuk melakukan pemantauan diri tiap anak (dalam hal ini mahasiswa, terutama mahasiswa yang melakukan karantina di tempat kost, asrama, atau kontrakan) setiap harinya mulai dari pengukuran suhu tubuh, penyediaan hand sanitizer setiap bulan, rutinitas mencuci tangan, catatan aktivitas di luar rumah, dan lainnya. Hasil pemantauan tersebut dapat ditulis dan diberikan kepada orang tua masing-masing dan dapat disimpan sebagai rekam jejak tiap bulan selama pandemi COVID-19.

Terdapat hubungan yang signifikan antara akses informasi dengan praktik personal hygiene responden. Hal ini terjadi karena keterpaparan informasi pada era digital saat ini tentu akan mempengaruhi kualitas wawasan yang didapat oleh mahasiswa dalam menanggapi hal-hal yang sedang menjadi topik permasalahan utama, terutama terkait pandemi COVID-19. Hal tersebut akan mempengaruhi pola pikir dan cara bertindak dari setiap individu mahasiswa terutama dalam memahami bahaya dan bentuk pencegahan COVID-19 saat ini.

Hal ini sesuai dengan teori Lawrance Green yang menyatakan bahwa akses informasi merupakan faktor yang memungkinkan alasan atau motivasi terhadap perilaku kesehatan tersebut agar dapat terlaksana (Green \& Kreuter, 1991; Porter, 2015). Informasi dapat berasal dari pengalaman pribadi, pengalaman orang lain, ilmu pengetahuan, maupun media sosial. Sumber informasi seperti media sosial merupakan sumber yang paling umum didapat dari kalangan mahasiswa di Universitas Mutah (Kozlakidis et al., 2019).

Informasi yang didapat mempengaruhi personal hygiene seseorang. Kurangnya informasi yang didapat menjadi potensi kurangnya implementasi dari personal hygiene seseorang. Hal ini tidak menutup kemungkinan kurang baiknya implementasi personal hygiene seseorang dipengaruhi oleh kesalahan informasi yang didapatkan. Sebagai mahasiswa yang sudah paham akan kredibilitas informasi seharusnya lebih mudah dalam memilah informasi yang didapat.

Praktik personal hygiene yang kurang baik lebih banyak ditemukan pada responden yang tidak dapat menjangkau akses informasi (52,5\%) daripada responden yang dapat menjangkau akses informasi $(30,7 \%)$ dengan hasil bahwa responden yang tidak dapat menjangkau akses informasi berisiko 2,493 kali lebih besar memiliki praktik personal hygiene yang kurang baik daripada responden yang dapat menjangkau akses informasi. Hal ini menguatkan bukti bahwa semakin tidak terjangkaunya akses informasi seseorang selama situasi pandemi COVID-19 saat ini, maka semakin kurang baik dan tidak maksimal pula implementasi pencegahan yang dilakukan, begitu pun sebaliknya. Terlihat dari jawaban responden bahwa mahasiswa mudah untuk memperoleh informasi terkait pentingnya menjaga dan memelihara personal hygiene selama pandemi COVID-19 $(98,2 \%)$ sehingga pada 
implementasinya telah baik dalam mencuci tangan menggunakan sabun dan air mengalir selama kurang lebih 20-30 detik (52,9\%). Hal tersebut didukung dengan penelitian yang dilakukan pada mahasiswa farmasi di Universitas British di Mesir bahwa adanya hubungan antara sumber informasi dengan praktik pencegahan COVID-19 (signifikan pada p<0,05) (Hamza, Badary, \& Elmazar, 2020).

Kalangan mahasiswa diharapkan dapat terus menyebarkan informasi dan edukasi terkait menjaga kualitas kebersihan pribadi sebagai bentuk pencegahan dalam situasi pandemi COVID saat ini. Hal ini dapat dilakukan dengan selalu memberikan informasi dan edukasi secara daring melalui media sosial. Informasi dan edukasi ini tidak hanya dapat diberikan ke teman-teman mahasiswa lainnya namun juga dapat disebarluaskan kepada keluarga dan masyarakat sekitarnya.

\section{Kesimpulan dan Saran}

Determinan yang berhubungan dengan praktik personal hygiene mahasiswa Universitas Diponegoro ialah jenis kelamin, sikap tentang praktik personal hygiene, dukungan sosial, dan akses informasi. Faktor predisposisi seperti jenis kelamin dan sikap, faktor penguat seperti dukungan sosial, serta faktor pemungkin seperti akses informasi memiliki peran penting dalam terciptanya praktik kesehatan, terutama dalam hal praktik personal hygiene untuk mencegah penularan COVID-19 sesuai dengan teori Lawrance Green.

Responden paling banyak berjenis kelamin perempuan $(71,7 \%)$, memiliki pengetahuan tentang praktik personal hygiene yang kurang baik $(27,4 \%)$, memiliki sikap tentang praktik personal hygiene yang kurang baik $(45,2 \%)$, memiliki lingkungan sosial yang tidak mendukung $(55,2 \%)$, tidak dapat menjangkau akses informasi $(46,2 \%)$, dan memiliki praktik personal hygiene yang kurang baik (40,7\%). Praktik personal hygiene kurang baik pada mahasiswa Universitas Diponegoro lebih banyak ditemukan pada mahasiswa berjenis kelamin laki-laki dan sikap tentang praktik personal hygiene yang kurang baik. Kampanye edukatif di kalangan mahasiswa dapat dilakukan agar mahasiswa dapat terlatih dan terbiasa dalam menyikapi dengan baik dan benar bentuk pencegahan melalui praktik personal hygiene selama pandemi COVID-19.

\section{Ucapan Terima Kasih}

Peneliti berterima kasih kepada seluruh mahasiswa Universitas Diponegoro yang telah bersedia dan ikut berpartisipasi menjadi responden dalam penelitian ini.

\section{Daftar Pustaka}

Green, L. W., \& Kreuter, M. W. (1991). Health Promotion Planning: An Educational and Environmental Approach (2nd ed.). Mayfield Publishing Company.

Hamza, M. S., Badary, O. A., \& Elmazar, M. M. (2020). Cross-Sectional Study on Awareness and Knowledge of COVID-19 Among Senior pharmacy Students. Journal of Community Health, 1-8. https://doi.org/10.1007/s10900-020-00859$\mathrm{Z}$

Komite Penanganan COVID-19 dan Pemulihan Ekonomi Nasional. (2020). Peta Sebaran COVID-19 7 Desember. Retrieved December 7, 2020, from https://covid19.go.id/peta-sebaran

Kozlakidis, Z., Jaber, H., Kim, J. U., Olaimat, A. N., Aolymat, I., Shahbaz, H. M., \& Holley, R. A. (2019). Knowledge and Information Sources About COVID-19 Among University Students in Jordan: A Cross-Sectional Study. Frontiers in Public Health, 8, 254. https://doi.org/10.3389/fpubh.2020.00254

Manyullei, S., Utama, D. A., \& Birawida, A. B. (2012). Gambaran Faktor Yang Berhubungan Dengan Penderita Kusta di Kecamatan Tamalate Kota Makassar. Indonesian Journal of Public Health, 1(1), 10-17.

Notoatmodjo, S. (2012). Promosi Kesehatan dan Perilaku Kesehatan. Jakarta: PT. Rineka Cipta.

Odonkor, S. T., Kitcher, J., Okyere, M., \& Mahami, T. (2019). Self-Assessment of Hygiene Practices towards Predictive and Preventive Medicine Intervention: A Case Study of University Students in Ghana. BioMed Research International, 1-10. https://doi.org/10.1155/2019/3868537

Peng, Y., Pei, C., Zheng, Y., Wang, J., \& Zhang, K. (2020). Knowledge, Attitude and Practice Associated with COVID-19 among University Students: a Cross-Sectional Survey in China. Research Square, (127), 1-24.

Porter, C. M. (2015). Revisiting Precede-Proceed: 
A leading model for ecological and ethical health promotion. Health Education Journal, 1-12.

https://doi.org/10.1177/0017896915619645

Prasetyo, Y. T., Castillo, A. M., Salonga, L. J., Sia, J. A., \& Seneta, J. A. (2020). Factors Affecting Perceived Effectiveness of COVID-19 Prevention Measures among Filipino during Enhanced Community Quarantine in Luzon, Philippines: Integrating Protection Motivation Theory and Extended Theory of Planned Behavior. International Journal of Infectious Diseases, 99, 312-323.

https://doi.org/10.1016/j.ijid.2020.07.074

Risnawaty, G. (2017). Faktor Determinan Perilaku Cuci Tangan Pakai Sabun (Ctps) Pada Masyarakat Di Tanah Kalikedinding. Jurnal PROMKES, 4(1), 70. https://doi.org/10.20473/jpk.v4.i1.2016.70 $-81$

Salman, M., Mustafa, Z. U., Asif, N., Haider, Zaidi, A., Hussain, Khalid, Saleem, Z. (2020). Knowledge, attitude and preventive practices related to COVID-19: a cross-sectional study in two Pakistani university populations. Drugs \& Therapy Perspectives, 1-7. https://doi.org/10.1007/s40267-020-007377

Saltzman, L. Y., Hansel, T. C., \& Bordnick, P. S. (2020). Loneliness, Isolation, and Social Support Factors in Post-COVID-19 Mental Health. Psychological Trauma: Theory, Research, Practice, and Policy, 12, 55-57. https://doi.org/10.1037/tra0000703
UNICEF. (2020). Cleaning and hygiene tips to help keep the COVID-19 virus out of your home. Retrieved June 17, 2020, from https://www.unicef.org/mena/stories/cle aning-and-hygiene-tips-help-keep-covid-19 -virus-out-your-home

White, S., Omer, M., \& Mohamma, G. N. (2020). Knowledge, Attitude and Practice on Prevention of Airborne and Droplet Infections During the Outbreak of Corona Virus among the College Students in University of Bisha, Saudi Arabia. International Journal of Contemporary Research and Review, 11(4), 20773-20776.

World Health Organization. (2020). Water, sanitation, hygiene, and waste management for the COVID-19 virus. World Health Organization, 1-9.

World Health Organization. (2020). Coronavirus Disease (COVID-19) Dashboard November 26th. Retrieved November 26, 2020, from https://covid19.who.int/

World Health Organization. (2020). WHO Coronavirus Disease (COVID-19) Dashboard December 7th. Retrieved December 7, 2020, from https://covid19.who.int/

Yuliana. (2020). Corona virus diseases (Covid -19); Sebuah tinjauan literatur. Wellness and Healthy Magazine, 2(1), 187-192. Retrieved from

https://wellness.journalpress.id/wellness/ article/view/v1i218wh 